$\sqrt{B}$

J. Bio-Sci. 27: 11-21, 2019

ISSN 1023-8654

http://www.banglajol.info/index.php/JBS/index

DOI: https://doi.org/10.3329/jbs.v27i0.44667

\title{
DEVELOPMENTAL PARAMETERS OF XYLOCHORIS FLAVIPES (REUTER) (HEMIPTERA: ANTHOCORIDAE) FED ON LIFE-STAGES OF RHYZOPERTHA DOMINICA (F.)
}

\author{
AC Sarker ${ }^{183}$, W Islam ${ }^{1 *}$ and S Parween ${ }^{2}$ \\ ${ }^{1}$ Institute of Biological Sciences, University of Rajshahi, Rajshahi 6205, Bangladesh \\ 2Department of Zoology, University of Rajshahi, Rajshahi 6205, Bangladesh \\ ${ }^{3}$ Department of Zoology, Carmaichel College, Rangpur, Bangladesh
}

\begin{abstract}
The hemipteran predator, Xylocoris flavipes (Reuter) predates the eggs, larvae and pupae of Rhyzopertha dominica (F.) in storage condition and checks their population in considerable level. The nymphs of $1^{\text {st }}$ up to $5^{\text {th }}$ instar and adults of $X$. flavipes were found efficient to survive on eggs, larvae of $1^{\text {st }}$ up to $4^{\text {th }}$ instar and pupae of $R$. dominica. The mean duration of developmental period through five nymphal instars on eggs, larvae of $1^{\text {st }}$ up to $4^{\text {th }}$ instars and pupae were $18 \pm 1.00,20 \pm 0.58,16 \pm 2.00$, $14 \pm 1.15,12 \pm 1.15$ and $13 \pm 0.58$ days in $R$. dominica. The adult female $X$. flavipes survived longer than the male. Average consumption rates of each nymph of $1^{\text {st }}$ up to $5^{\text {th }}$ instar and adult stage of $X$. flavipes were found highest on eggs, $1^{\text {st }}$ and $2^{\text {nd }}$ instar larvae but lowest on $4^{\text {th }}$ instar larvae and pupae. The female predator always consumed more individuals than the male. Average survivability rates of nymphs of $1^{\text {st }}$ up to $5^{\text {th }}$ instar and adults were maximum on $1^{\text {st }}$ and $2^{\text {nd }}$ instar larvae and minimum on $4^{\text {th }}$ instar larvae and pupae. The size of the female predator was found larger than the male at all the stages. Based on the ratio 1:1, sex ratio was the best (male and female almost equal in number) on $1^{\text {st }}$ and $2^{\text {nd }}$ instar larvae comparatively than that of other stages. Developmental period, adult longevity, consumption rate, survivability rate, size and sex ratio of $X$. flavipes were found always significant $(p<0.001)$ in different life stages of $R$. dominica. This study reveals that mass culture of $X$. flavipes can be established on $R$. dominica in the laboratory to get easy and abundant supply of the bug as an agent of biological control.
\end{abstract}

Key words: Biological parameters, Host life-stage, Rhyzopertha dominica, X. flavipes

\section{Introduction}

A large number of insect pests have been reported to be associated with grains, cereals, pulses, spices and other stored stuffs. The biological activities of these pests cause weight and quality loss of the storedproducts (Krishnamurthy 1975, Watters and Shuyler 1977, Hill 1978, Wilbur and Mills 1978, Burkholder and Faustini 1991, Khan and Mannan 1991), by secreting chemicals, releasing frass and faeces. The contaminated food stuffs are proved as health risk for the human being (Hansen 2010). In developed countries grains can be downgraded or rejected completely if even a single live insect or their body parts are found (Pinniger et al. 1984, Anonymous 1990). Management of stored product insects is facing challenges like restrictions on the use of pesticides, evolution of insecticide resistance in pest populations (Hagstrum et al. 1999, Phillips et al. 2000), and the chemical pesticides are in use creating hazards to the environment and its biota (Hagstrum et al. 1999, Phillips et al. 2000, Daglish and Wallbank 2002, Nayak et al. 2005, Daglish and Nayak 2006). Almost several pest species have remarkably high rates of reproduction and within one

*Author for correspondence: mwislam18@gmail.com 
season, may destroy 10-15 percent of the grains and contaminate the rest with undesirable odors' and flavors' (Khan and Mannan 1991). The loss in quality and quantity of the store grains and cereals and other food stuffs due to insect attack is a major threat for the future food security of a nation. So, worldwide researches are going on in search of alternative insect control measures in stored environment. Among the different alternative options for insect control the biological control has attracted the interest of the storedproduct entomologists because these agents are naturally present in the same environment that of the pest insects, pose reduced risks for beneficial insects, benign for the environment and its biota, and safe for human health.

Among major insect pests the lesser grain borer, Rhyzopertha dominica $(F$.$) is a member of the family$ Bostrichide and order Coleoptera. Both larvae and adults are primary pests of wheat, corn, rice and millet grains. The larvae bore irregular-shaped holes in undamaged whole kernels and immature stages develop inside the grain. Larvae and adults feeding in and on grain kernels leave only dust and thin brown shells of the infested grains. A sweet, musty odor is often associated with infestations of this insect. $R$. dominica is distributed in the temperate and tropical regions of the world (Edde 2012) including Bangladesh.

Many species of insect natural enemies occur in stored-product ecosystems (Brower et al. 1996); some of them are potential biological control agents for pests. The ware house pirate bug, Xylocoris flavipes (Reuter), member of subfamily Lyctocorinae, is a cosmopolitan predator and known to be potential in controlling at least 13 insect pest species of the grain and food stores (Ahmed et al. 1991, Brower et al. 1996, Scholler et al. 1997, Visarthanonth et al. 1990, 1994, Imamura et al. 2008). The efficacy of $X$. flavipes as a biological control agent was reported in several studies in which experimental prey populations were suppressed (Jay et al. 1968, Press et al. 1975, Le Cato and Collins 1976, Arbogast 1976, Keever et al. 1986, Brower and Press 1992). This hemipteran predator preys on egg, larval instars and pupae of different insect species including $R$. dominica, and potentiality of preying depends on the size (Le Cato and Davids 1973) and age of the prey insect (Vinson and Iwantsch 1980). Biology of X. flavipes is limited by the factors like temperature, humidity and food of the host species (Birch 1945 a,b\&c, Arbogast 1975, Press et al. 1976, Russo and Vasta 2004, Herrera et al. 2005, Ferdous 2006, Ferdous et al. 2009, Rahman et al. 2009). This paper is designed to study the biological parameters of Xylocoris flavipes while preying on different life-stages of $R$. dominica.

\section{Materials and Methods}

Collection and rearing of host, $R$. dominica: Adults of $R$. dominica were collected from the stock culture maintained in the Entomology and Insect Biotechnology Laboratory, Institute of Biological Sciences, University of Rajshahi, since 15 years having no history of insecticide exposure. The stock culture was maintained on standard food medium (whole wheat flour and powdered Brewer's yeast in a ratio of 19:1) (Park and Frank 1948, Park 1962, Zyromska-Rudzka 1996) and at $30 \pm 1^{\circ} \mathrm{C}$ and $70 \pm 0.5 \% \mathrm{RH}$ (relative humidity) in a CT (Controlled Temperature) room. Though, the normal food of $R$. dominica is whole wheat grain rather than flour, but flour medium was used to have easy supply of larvae and pupae by simply sieving the flour.

About 500 adult beetles were collected and divided into five groups consist of 100 adults. Beetles of each group were kept in $500 \mathrm{ml}$ beaker provided with $25 \mathrm{~g}$ of sterilized standard food medium. Few pieces of crumpled filter papers were placed in the beaker for easy movement of the beetles. Mouth of the beaker was covered with a piece of fine cloth and rubber band, to prevent escape of the beetles. The food was replaced by a fresh one after every three days.

Collection of eggs: After $24 \mathrm{~h}$ of setting the culture eggs were collected by sieving the adults through 125 micrometer aperture sieve. The collected eggs were kept on a piece of black paper. Eggs were cleaned 
using a fine camel hair brush, and by gently tapping the paper they were separated from the flour particles. Cleaned eggs were identified under compound microscope and transferred to petri dishes with the help of fine camel hair brush. Eggs were kept 3-4 days (d) for hatching.

Collection of larvae, pre-pupae, pupae and adults: After hatching, $1^{\text {st }}, 2^{\text {nd }}, 3^{\text {rd }}$ and $4^{\text {th }}$ instar larvae were obtained from 4-5d, 5-6d, 4-5d and 6-7d culture respectively. Pre pupae and pupae were seen into the cocoon at 9-11d and 13-16d respectively. The larvae and pupae were collected by dissecting infested wheat grains and confirmed by random examining through a magnifying glass. Pupae emerged as adults at its 4-5 days. All the cultures were conducted in the CT room at $30 \pm 0.5^{\circ} \mathrm{C}$ temperature and $70 \pm 0.5 \%$ relative humidity to ensure constant and regular supply of different life stages of $R$. dominica of known age throughout the study period.

Collection and rearing of predator, $X$. flavipes: Adult $X$. flavipes were collected from the stock culture maintained in the Entomology and Insect Biotechnology Laboratory, Institute of Biological Sciences, University of Rajshahi since 10 years having no history of insecticide exposure. The bugs were reared on eggs, larvae up to $4^{\text {th }}$ instar and pupae of $R$. dominica at $30 \pm 1^{\circ} \mathrm{C}$ and $70 \pm 0.5 \% \mathrm{RH}$ in the aforesaid $\mathrm{CT}$ room. For constant supply of predators, $50 \mathrm{~g}$ of standard food of the host insect was kept in the culture container. After every three days the host's food was replaced by fresh ones. Two hundred unsexed adult predators were kept separately in $500 \mathrm{ml}$ beaker provided with sufficient food (1 $1^{\text {st }}$ and $2^{\text {nd }}$ instar larvae and pupae of $R$. dominica). After $24 \mathrm{~h}$ adults were replaced with the help of a fine camel brush. Eggs were found at the bottom of the beaker and examined them under compound microscope. The collected eggs were kept about $4-5 d$ for hatching.

Collection of nymphs and adults of $X$. flavipes: The newly hatched nymphs were determined by using magnifying glass and transferred very carefully with the help of fine camel hair brush to a beaker $(500 \mathrm{ml})$ containing $1^{\text {st }}$ and $2^{\text {nd }}$ instar larvae of $R$. dominica as food. The $2^{\text {nd }}, 3^{\text {rd }}, 4^{\text {th }}$ and $5^{\text {th }}$ instar nymphs were obtained from the culture on the $3^{\text {rd }}, 5^{\text {th }}, 8^{\text {th }}$ and $12^{\text {th }} \mathrm{d}$ from hatching respectively. The nymphal instars were estimated by counting the exuviae deposited in the petri dish. The $5^{\text {th }}$ instar nymphs were allowed to emerge as adults.

Determination of sex: Sex of $X$. flavipes bugs were separated at the adult stage. Shape of the adult female's abdomen is bilaterally symmetrical and in male it is notched on the left side of the segments 8 and 9. The sex character of the adults was examined under a stereo binocular microscope.

Bioassays: Newly hatched healthy 70 nymphs of $X$. flavipes were kept in 7 petri dishes $(9 \mathrm{~cm}$ diam.) separately (10 nymphs per Petri dish). Live 200 eggs or 25 larvae of each instar (15t - $\left.4^{\text {th }}\right)$ separately, or 10 pupae of $R$. dominica were given as food. After every $24 \mathrm{~h}$, consumed or killed life stages of $R$. dominica by $X$. flavipes were observed and counted. Foods were balanced by adding same life stage of the prey insect and were cleaned discarding the dead insects daily. The nymphs were regularly observed for ecdysis, number of nymphal ecdysis was recorded alone with the duration of each instar. Regular supply of eggs, larvae up to $4^{\text {th }}$ instar and pupae of $R$. dominica was maintained until the death of $X$. flavipes.

Parameters studied: The following biological parameters of $X$. flavipes fed on $R$. dominica were studied: nymphal developmental time, longevity of adult males and females, prey consumption rate, number of survivability, size of male and female adults (length in $\mathrm{mm}$, measured by an ocular micrometer) and number and sex-ratio of male and female. All the experiments were replicated thrice times.

Data analysis: Difference in the effects on the biological parameters of the predator while preying on different life stages of the host insect was compared using the factorial ANOVA. The comparison between 
the mean values of individual parameters was compared by Tukey's test (1953). Significant difference between the sex-ratio of the predator was tested using $\times 2$ test.

\section{Results and Discussion}

\section{Developmental period of $X$. flavipes}

$X$. flavipes was found able to complete development on eggs, larvae (1st up to 4th instar) and pupae of $R$. dominica, but the bugs do not prey on the adult beetles. The developmental period of each nymphal instar of the predator was found to vary while feeding on different life stages of the host. The minimum developmental time was recorded as $12 \pm 1.15 \mathrm{~d}$ when $X$. flavipes nymphs were preyed on the $4^{\text {th }}$ instar larvae of $R$. dominica, and development was delayed as $20 \pm 0.58 \mathrm{~d}$ when preyed on $2^{\text {nd }}$ instar larvae of the host (Table 1). Total nymphal developmental time varied significantly while the predator preyed on different life stages of the host (Table 2). Developmental time needed for each nymphal instar was more or less similar and not related to the host's life stage.

Table 1. Developmental periods and adult longevity of $X$. flavipes fed on different life stages of $R$. dominica under laboratory condition

\begin{tabular}{|c|c|c|c|c|c|c|c|c|c|c|}
\hline \multirow{2}{*}{$\begin{array}{c}\text { Life stages } \\
\text { of } \\
\text { R.dominica }\end{array}$} & \multicolumn{4}{|c|}{$\begin{array}{l}\text { Mean Developmental periods (day) of } \\
\text { instar }\end{array}$} & nymphal & \multirow{2}{*}{$\begin{array}{l}\text { Total duration } \\
\text { (day) of } \\
\text { nymphal } \\
\text { stages }\end{array}$} & \multicolumn{2}{|c|}{$\begin{array}{l}\text { Adult longevity (day) } \\
\text { of } X \text {. flavipes }\end{array}$} & \multicolumn{2}{|c|}{$\begin{array}{l}\text { Total duration } \\
\text { (day) }\end{array}$} \\
\hline & $1^{\text {st }}$ & $2^{\text {nd }}$ & $3^{\text {rd }}$ & $4^{\text {th }}$ & $5^{\text {th }}$ & & Male & Female & Male & Female \\
\hline Eggs (larvae) & $3 \pm 0.58 \mathrm{a}$ & $3 \pm 0.58 \mathrm{a}$ & $4 \pm 0.58 \mathrm{ab}$ & $4 \pm 0.58 \mathrm{ab}$ & $4 \pm 0.58 \mathrm{a}$ & $18 \pm 1.00 \mathrm{bab}$ & $10 \pm 2.31 b$ & $22 \pm 3.46 \mathrm{bc}$ & 28 & 40 \\
\hline $1^{\text {st }}$ & $4 \pm 0.58 \mathrm{a}$ & $3 \pm 0.58 \mathrm{a}$ & $4 \pm 0.58 \mathrm{a}$ & $5 \pm 0.58 \mathrm{a}$ & $4 \pm 0.58 \mathrm{a}$ & $20 \pm 0.58 a$ & $12 \pm 1.15 a b$ & $26 \pm 0.88 a b$ & 32 & 46 \\
\hline $2^{\text {nd }}$ & $3 \pm 0.58 \mathrm{a}$ & $2 \pm 0.58 \mathrm{a}$ & $3 \pm 0.58 \mathrm{a}$ & $4 \pm 0.58 \mathrm{ab}$ & $4 \pm 0.58 \mathrm{a}$ & $16 \pm 2.00 \mathrm{abc}$ & $18 \pm 0.58 \mathrm{a}$ & $34 \pm 2.31 \mathrm{a}$ & 34 & 50 \\
\hline $3^{\text {rd }}$ & $3 \pm 0.58 \mathrm{a}$ & $2 \pm 0.58 \mathrm{a}$ & $3 \pm 0.58 \mathrm{a}$ & $3 \pm 0.58 \mathrm{ab}$ & $3 \pm 0.58 \mathrm{a}$ & $14 \pm 1.15 b c$ & $10 \pm 1.33 b$ & $24 \pm 2.31 b c$ & 24 & 38 \\
\hline $4^{\text {th }}$ & $3 \pm 0.58 \mathrm{a}$ & $2 \pm 0.58 \mathrm{a}$ & $2 \pm 0.58 \mathrm{a}$ & $2 \pm 0.58 \mathrm{~b}$ & $3 \pm 0.58 \mathrm{a}$ & $12 \pm 1.15 \mathrm{c}$ & $8 \pm 1.15 b$ & $20 \pm 1.15 b c$ & 20 & 32 \\
\hline Pupae & $3 \pm 0.0 \mathrm{a}$ & $2 \pm 0.0 \mathrm{a}$ & $3 \pm 0.58 \mathrm{a}$ & $2 \pm 0.58 \mathrm{~b}$ & $3 \pm 58.0 \mathrm{a}$ & $13 \pm 0.58 b c$ & $5 \pm 0.58 \mathrm{~b}$ & $15 \pm 1.15 \mathrm{c}$ & 18 & 28 \\
\hline
\end{tabular}

Note: Means with same letter do not significantly differed from each other Tukey's Test, $p<0.001$

Table 2. ANOVA results on the effects of different life stages of $R$. dominica (host) on the developmental period of different nymphal stages and adult longevity of $X$. flavipes

\begin{tabular}{|l|c|c|c|c|c|c|c|}
\hline \multirow{2}{*}{ Factors (df) } & \multicolumn{2}{|c|}{ F-values (level of significance) at nymphal instars of $X$. flavipes } & \multicolumn{2}{c|}{ Adult $X$. flavipes } \\
\cline { 2 - 8 } & 1st & 2nd & $3^{\text {rd }}$ & 4th & 5th & Male & Female \\
\hline $\begin{array}{l}\text { Life stages of } \\
\text { host (5) }\end{array}$ & $\begin{array}{c}13.76 \\
(\mathrm{P}=0.054)\end{array}$ & $\begin{array}{c}19.60 \\
(\mathrm{P}=0.054)\end{array}$ & $\begin{array}{c}17.29 \\
(\mathrm{P}=0.242)\end{array}$ & $\begin{array}{c}12.39 \\
(\mathrm{P}=0.061)\end{array}$ & $\begin{array}{c}9.92 \\
(\mathrm{P}=0.071)\end{array}$ & $\begin{array}{c}10.91 \\
(\mathrm{P}=0.072)\end{array}$ & $\begin{array}{c}8.77 \\
(\mathrm{P}=0.015)\end{array}$ \\
\hline Replications (2) & $\begin{array}{c}8.93 \\
(\mathrm{P}=0.157)\end{array}$ & $\begin{array}{c}12.92 \\
(\mathrm{P}=0.125)\end{array}$ & $\begin{array}{c}11.35 \\
(\mathrm{P}=0.142)\end{array}$ & $\begin{array}{c}7.72 \\
(\mathrm{P}=0.125)\end{array}$ & $\begin{array}{c}6.04 \\
(\mathrm{P}=0.136)\end{array}$ & $\begin{array}{c}6.96 \\
(\mathrm{P}=0.145)\end{array}$ & $\begin{array}{c}5.71 \\
(\mathrm{P}=0.132)\end{array}$ \\
\hline Host & $\begin{array}{c}5.17 \\
\text { Replication }\end{array}$ & $\begin{array}{c}5.78 \\
(\mathrm{P}=0.362)\end{array}$ & $\begin{array}{c}6.64 \\
(\mathrm{P}=0.326)\end{array}$ & $\begin{array}{c}4.73 \\
(\mathrm{P}=0.148)\end{array}$ & $\begin{array}{c}3.67 \\
(\mathrm{P}=0.138)\end{array}$ & $\begin{array}{c}4.37 \\
(\mathrm{P}=0.134)\end{array}$ & $\begin{array}{c}3.68 \\
(\mathrm{P}=0.164)\end{array}$ \\
\hline
\end{tabular}




\section{Adult longevity and total life span of $X$. flavipes}

Life span of the predator varied with the different life stages of host. Adult of $X$. flavipes were found to prey very actively on $2^{\text {nd }}$ and $3 r d$ instar larvae of the host. The maximum longevity of the females was $34 \pm 2.31 \mathrm{~d}$ and the minimum longevity was $15 \pm 1.15 \mathrm{~d}$, while feeding on $2^{\text {rd }}$ instar larvae and pupae of $R$. dominica respectively. In case of males the maximum longevity $18 \pm 0.58 \mathrm{~d}$ and the minimum longevity $5 \pm 0.58 \mathrm{~d}$, when they fed on 2nd instar larvae and pupae respectively (Table 1). The effect of different life stages of prey on adult longevity of $X$. flavipes was significant (Table 2). Total life span of $X$. flavipes was found to range from 28-50d (female) and 18-34d (male) (Table 1).

\section{Prey consumption rate of $X$. flavipes}

Average prey consumption rate was found to differ depending on the life stages of $R$. dominica. The predator preyed maximum number of eggs compared to other stages of the] beetles; the pupae of the host were least prefered by all the life stages of the predator (Table 3). The number of eggs preyed varied at different nymphal instars, and the number of prey was increased with the increased age of the nymphs. The range of number of eggs preyed by a single predator were recorded as $8 \pm 0.58$ to $19.33 \pm 0.88$ per day by the $1^{\text {st }}$ and $5^{\text {th }}$ instar nymphs respectively. A male predator fed on $21.33 \pm 0.88$ eggs, and a female predator fed on $24.67 \pm 0.12$ eggs (Table 3). Whereas, the number of pupae preyed per day by single predator was found to range from $1 \pm 0.33$ to $2.33 \pm$ 0.88 for the $1^{\text {st }}$ and $5^{\text {th }}$ instar larvae respectively. The male and female predator consumed $2.33 \pm 0.88$ and $3 \pm 0.05$ pupae of $R$. dominica per day respectively, and the female predator always consumed more prey than the male.

Prey consumption rate was significantly dependent on the life stages of the host (Table 4).

Table 3. Average (\%) consumption rate by different life stages of $X$. flavipes per day on different life stages of $R$. dominica under laboratory condition

\begin{tabular}{|c|c|c|c|c|c|c|c|}
\hline \multirow{3}{*}{$\begin{array}{l}\text { Life stages of } \\
\text { R. dominica }\end{array}$} & \multicolumn{7}{|c|}{ Average (\%) consumption rate of $X$. flavipes } \\
\hline & \multicolumn{5}{|c|}{ Nymphs (instars) } & \multicolumn{2}{|c|}{ Adults } \\
\hline & $1^{\text {st }}$ & $2^{\text {nd }}$ & $3^{\text {rd }}$ & $4^{\text {th }}$ & $5^{\text {th }}$ & Male & Female \\
\hline Eggs (larvae) & $8 \pm 0.583 a$ & $10.67 \pm 0.67 a$ & $14.33 \pm 0.88 a$ & $16.67 \pm 1.20 \mathrm{a}$ & $19.33 \pm 0.88 a$ & $21.33 \pm 0.88 a$ & $24.67 \pm 1.2 a$ \\
\hline $1^{\text {st }}$ & $3.33 \pm 0.88 b$ & $4.67 \pm 1.2 b$ & $5 \pm 0.58 b$ & $6.33 \pm 0.88 \mathrm{~b}$ & $8.67 \pm 1.2 b$ & $10 \pm 1.15 b$ & $14 \pm 1.15 b$ \\
\hline $2^{\text {nd }}$ & $2.33 \pm 0.88 b$ & $3.67 \pm 1.2 b$ & $4.33 \pm 0.88 b$ & $5.67 \pm 1.2 b$ & $7.33 \pm 0.88 b$ & $9.33 \pm 0.88 \mathrm{~b}$ & $12.33 \pm 0.88 \mathrm{c}$ \\
\hline $3^{\text {rd }}$ & $2 \pm 0.58 \mathrm{bc}$ & $3.33 \pm 0.88 \mathrm{~b}$ & $4 \pm 0.58 \mathrm{~b}$ & $5 \pm 0.58 b$ & $6.67 \pm 1.2 \mathrm{c}$ & $8.67 \pm 0.33 c b$ & $11.33 \pm 0.88 \mathrm{c}$ \\
\hline $4^{\text {th }}$ & $1.33 \pm 0.33 b$ & $2.33 \pm 0.88 b$ & $2.67 \pm 1.2 b$ & $3.33 \pm 1.45 b$ & $4.33 \pm 0.88 \mathrm{c}$ & $6.33 \pm 0.88 \mathrm{c}$ & $8.33 \pm 0.88 \mathrm{~cd}$ \\
\hline Pupae & $1 \pm 0.0 \mathrm{~b}$ & $1.33 \pm 0.33 \mathrm{~b}$ & $1.67 \pm 0.33 \mathrm{~b}$ & $2 \pm 0.58 \mathrm{~b}$ & $2.33 \pm 0.88 \mathrm{c}$ & $3 \pm 0.058 \mathrm{c}$ & $4 \pm 0.58 d$ \\
\hline
\end{tabular}

Note: Means with same letter do not significantly differ from each other Tukey's Test, $p<0.001$ 
Table 4. ANOVA results on the average (\%) consumption of different life stages of $R$. dominica (host) by nymphal instars and adults of $X$. flavipes

\begin{tabular}{|l|c|c|c|c|c|c|c|}
\hline \multirow{2}{*}{ Factors (df) } & \multicolumn{4}{|c|}{ F-values (level of significance) at nymphal instars of $X$. flavipes } & \multicolumn{2}{l|}{ Adult $X$. flavipes } \\
\cline { 2 - 8 } & 1st & 2nd & 3rd $^{\text {rd }}$ & 4th & 5th & Male & Female \\
\hline $\begin{array}{l}\text { Life stages of } \\
\text { host (5) }\end{array}$ & $\begin{array}{c}202.08 \\
(P=0.001)\end{array}$ & $\begin{array}{c}214.5 \\
(P=0.003)\end{array}$ & $\begin{array}{c}167.69 \\
(P=0.004)\end{array}$ & $\begin{array}{c}178.58 \\
(P=0.005)\end{array}$ & $\begin{array}{c}189.542 \\
(P=0.002)\end{array}$ & $\begin{array}{c}194.07 \\
(P=0.021)\end{array}$ & $\begin{array}{c}199.44 \\
(P=0.002)\end{array}$ \\
\hline Replications (2) & $\begin{array}{c}0.86 \\
(P=0.765)\end{array}$ & $\begin{array}{c}0.91 \\
(P=0.745)\end{array}$ & $\begin{array}{c}0.733 \\
(P=0.369)\end{array}$ & $\begin{array}{c}0.79 \\
(P=0.335)\end{array}$ & $\begin{array}{c}0.86 \\
(P=0.333)\end{array}$ & $\begin{array}{c}0.85 \\
(P=0.312)\end{array}$ & $\begin{array}{c}1.01 \\
(P=0.452)\end{array}$ \\
\hline Host & 1.88 & $\begin{array}{c}1.98 \\
(P=0.623)\end{array}$ & $\begin{array}{c}1.57 \\
(P=0.758)\end{array}$ & $\begin{array}{c}1.67 \\
(P=0.726)\end{array}$ & $\begin{array}{c}1.77 \\
(P=0.632)\end{array}$ & $\begin{array}{c}0.82 \\
(P=0.425)\end{array}$ & $\begin{array}{c}1.84 \\
(P=0.458)\end{array}$ \\
\hline
\end{tabular}

Survivability of $X$. flavipes: Survivability rate of the predator varied with the life stages of the host. Mean survivability of the nymphal instars was higher when preyed on larval instars of the host than their pupae (Table 5). Survivability of male adults was higher when preyed on $1^{\text {st }}$ instar larvae, and that of female adults was higher when fed on $1^{\text {st }}$ to $4^{\text {th }}$ instar larvae of the prey insect (Table 5). Survivability rate of $X$. flavipes significantly varied on different life stages of $R$. dominica (Table 6 ).

\section{Size of $X$. flavipes fed on different life stages of $R$. dominica}

Normally females are larger in size than males. Size of males $(1.85 \pm 0.03 \mathrm{~mm})$ and females $(2.2 \pm 0.06 \mathrm{~mm})$ were greater when they preyed on $2^{\text {nd }}$ and $1^{\text {st }}$ instar larvae of $R$. dominica respectively. The adult size was minimum when they fed on the pupae of the host insect (Table 7). Adult size of the predator varied significantly with the different life stages of the host insect (Table 8).

Table 5. Average number ( $\pm S E$ ) of survivability of different life stages of $X$. flavipes on different life stages of $R$. dominica

\begin{tabular}{|c|c|c|c|c|c|c|c|}
\hline \multirow{3}{*}{$\begin{array}{c}\text { Life stages of } \\
\text { R.dominica }\end{array}$} & \multicolumn{7}{|c|}{ Average (\%) no. of survivability of $X$. flavipes } \\
\hline & \multicolumn{5}{|c|}{ Nymphs (instars) } & \multicolumn{2}{|c|}{ Adults } \\
\hline & $1^{\text {st }}$ & $2^{\text {nd }}$ & $3^{\text {rd }}$ & $4^{\text {th }}$ & $5^{\text {th }}$ & Male & Female \\
\hline Eggs (larvae) & $9.00 \pm 0.58 \mathrm{a}$ & $8 \pm 0.58 \mathrm{ab}$ & $7.33 \pm 0.67 a b$ & $6 \pm 0.33 a$ & $5.67 \pm 0.33 a$ & $4.33 \pm 1.2 \mathrm{a}$ & $5.67 \pm 0.67 a$ \\
\hline $1^{\text {st }}$ & $9.33 \pm 0.33 a$ & $8.67 \pm 0.33 \mathrm{a}$ & $8.33 \pm 0.33 a$ & $7 \pm 0.58 \mathrm{a}$ & $6 \pm 0.58 \mathrm{a}$ & $3 \pm 0.58 \mathrm{a}$ & $7 \pm 0.58 \mathrm{a}$ \\
\hline $2^{\text {nd }}$ & $8 \pm 0.58 a b$ & $7 \pm 0.12 b$ & $6.67 \pm 0.33 \mathrm{ab}$ & $6.33 \pm 0.33 a$ & $5.67 \pm 0.33 a$ & $2.67 \pm 0.33 a$ & $6.33 \pm 0.88 a$ \\
\hline $3^{\text {rd }}$ & $8.33 \pm 0.33 a b$ & $7.67 \pm 0.33 a b$ & $6.33 \pm 0.33 \mathrm{~b}$ & $6.00 \pm 0.58 a$ & $5 \pm 1.45 a$ & $3.33 \pm 1.45 a$ & $6.67 \pm 0.33 a$ \\
\hline $4^{\text {th }}$ & $7.33 \pm 0.33 a b$ & $7 \pm 0.58 \mathrm{~b}$ & $5.67 \pm 0.33 b c$ & $5.00 \pm 0.58 \mathrm{ab}$ & $4.33 \pm 0.33 a b$ & $3 \pm 0.33 a$ & $6 \pm 0.33 a$ \\
\hline Pupae & $6.33 \pm 0.58 a$ & $5.33 \pm 0.33 c$ & $4.33 \pm 0.33 a b$ & $3.67 \pm 0.33 b$ & $2.67 \pm 0.33 b$ & $2+0.33 a$ & $5 \pm 1 a$ \\
\hline
\end{tabular}

Note: Means with same letter do not significantly differ from each other Tukey's Test, $P<0.001$ 
Table 6. ANOVA results on the average number of survivability of different life stages of $X$. flavipes on different life stages of $R$. dominica

\begin{tabular}{|c|c|c|c|c|c|c|c|}
\hline \multirow{2}{*}{ Factors (df) } & \multicolumn{4}{|c|}{ F-values (significance level) at nymphal instars of $X$. flavipes } & \multicolumn{2}{|c|}{ Adult $X$. flavipes } \\
\cline { 2 - 8 } & $\mathbf{1}^{\text {st }}$ & 2nd & 3rd & $\mathbf{4}^{\text {th }}$ & 5th & Male & Female \\
\hline $\begin{array}{c}\text { Life stages of } \\
\text { host (5) }\end{array}$ & $\begin{array}{c}37.41 \\
(P=0.000)\end{array}$ & $\begin{array}{c}36.89 \\
(P=0.001)\end{array}$ & $\begin{array}{c}36.06 \\
(P=0.001)\end{array}$ & $\begin{array}{c}42.27 \\
(P=0.001)\end{array}$ & $\begin{array}{c}57.56 \\
(P=0.002)\end{array}$ & $\begin{array}{c}38.59 \\
(P=0.002)\end{array}$ & $\begin{array}{c}41.95 \\
(P=0.002)\end{array}$ \\
\hline Replications (2) & $\begin{array}{c}5.01 \\
(P=0.025)\end{array}$ & $\begin{array}{c}4.93 \\
(P=0.022)\end{array}$ & $\begin{array}{c}4.83 \\
(P=0.022)\end{array}$ & $\begin{array}{c}4.53 \\
(P=0.022)\end{array}$ & $\begin{array}{c}4.35 \\
(P=0.021)\end{array}$ & $\begin{array}{c}4.57 \\
(P=0.022)\end{array}$ & $\begin{array}{c}5.14 \\
(P=0.022)\end{array}$ \\
\hline $\begin{array}{c}\text { Host* } \\
\text { Replication }\end{array}$ & $\begin{array}{c}1.23 \\
(P=0.387)\end{array}$ & $\begin{array}{c}1.21 \\
(P=0.147)\end{array}$ & $\begin{array}{c}1.19 \\
(P=0.147)\end{array}$ & $\begin{array}{c}1.92 \\
(P=0.149)\end{array}$ & $\begin{array}{c}2.52 \\
(P=0.485)\end{array}$ & $\begin{array}{c}1.85 \\
(P=0.471)\end{array}$ & $\begin{array}{c}3.35 \\
(P=0.471)\end{array}$ \\
\hline
\end{tabular}

\section{Adult number and sex-ratio of $X$. flavipes}

Mean number of male predator was found to range from $27 \pm 3.46$ to $42 \pm 2.31$ feeding on pupae and $2^{\text {nd }}$ instar larvae of $R$. dominica; the number of females ranged from $58 \pm 2.31$ to $73 \pm 3.46$ feeding on $1^{\text {st }}$ instar and pupae of the beetle respectively (Table 7). Number of adults was significantly varied when fed on the host (Table 8). Sex ratio of the male and female of $X$. flavipes was different when fed on different life stages of the host. However, the sex-ratio was not significantly differed from 1:1, except when they fed on the pupae of $R$. dominica (Table 5).

Table 7. Average ( $\pm S E$ ) adult size ( $\mathrm{mm}$ in length) and number of male and female $X$. flavipes preyed on different life stages of $R$. dominica

\begin{tabular}{|c|c|c|c|c|c|c|c|}
\hline \multirow{2}{*}{$\begin{array}{c}\text { Parameters } \\
\text { of } \\
\text { X. flavipes) }\end{array}$} & \multirow[t]{2}{*}{ Sex } & \multicolumn{6}{|c|}{ Different life stages of $R$. dominica } \\
\hline & & Eggs & $1^{\text {st }}$ & $2^{\text {nd }}$ & $3^{\text {rd }}$ & $4^{\text {th }}$ & Pupae \\
\hline \multirow{2}{*}{$\begin{array}{c}\text { Adult size ( } \pm \\
\mathrm{mm} \text { in length) } \\
\mathrm{n}=70\end{array}$} & Male & $1.75 \pm 0.03 a b$ & $1.8 \pm 0.02 \mathrm{a}$ & $1.85 \pm 0.03 a$ & $1.81 \pm 0.03 a$ & $1.76 \pm 0.03 a b$ & $1.65 \pm 0.04 b$ \\
\hline & Female & $2 \pm 0.06 \mathrm{bcd}$ & $2.2 \pm 0.06 \mathrm{a}$ & $2.0015 \pm 0.03 a b$ & $2.1 \pm 0.01 a b c$ & $1.98 \pm 0.05 \mathrm{~cd}$ & $1.9 \pm 0.03 \mathrm{~d}$ \\
\hline \multirow{2}{*}{$\begin{array}{c}\text { Number of } \\
\text { Adults }(n=70)\end{array}$} & Male & $37 \pm 1.73 a b c$ & $42 \pm 2.31 a$ & $39 \pm 2.89 \mathrm{ab}$ & $34 \pm 1.15 a b c$ & $31 \pm 0.58 b c$ & $27 \pm 3.46 \mathrm{a}$ \\
\hline & Female & $63 \pm 1.73 a b$ & $58 \pm 2.31 \mathrm{~b}$ & $61+2.89 b$ & $66 \pm 2.31 a b$ & $69 \pm 2.85 a b$ & $73 \pm 3.46 a$ \\
\hline Sex-ratio & Male: Female & $1: 1.7$ & 1:1.38 & 1:1.56 & 1:1.94 & $1: 2.2$ & $1: 2.7$ \\
\hline $\begin{array}{l}x 2-\text { value } \\
(d f=1)\end{array}$ & - & $\begin{array}{c}1.49 \\
\text { (insignificant) }\end{array}$ & $\begin{array}{c}1.14 \\
\text { (insignificant) }\end{array}$ & 1.13 (insignificant) & $\begin{array}{c}1.88 \\
\text { (insignificant) }\end{array}$ & $\begin{array}{c}2.44 \\
\text { (insignificant) }\end{array}$ & $\begin{array}{c}3.89 \\
\text { (significant } \\
0.05 \text { ) }\end{array}$ \\
\hline
\end{tabular}

Note: Means with same letter do not significantly differed from each other Tukey's Test, $p<0.001$ 
Table 8. ANOVA results on the average adult size $(\mathrm{mm})$ and number of male-female $X$. flavipes on different life stages of $R$. dominica

\begin{tabular}{|c|c|c|c|c|c|c|c|c|}
\hline \multirow{2}{*}{ Factors (df) } & \multicolumn{4}{|c|}{ Size of Adult X. flavipes (mm) } & \multicolumn{4}{c|}{ Number of Adult X. flavipes } \\
\cline { 2 - 9 } & \multicolumn{2}{|c|}{ Male } & \multicolumn{2}{c|}{ Female } & \multicolumn{2}{c|}{ Male } & \multicolumn{2}{c|}{ Female } \\
\cline { 2 - 9 } & F-value & $\mathbf{P}$ & F-value & $\mathbf{P}$ & F-value & $\mathbf{P}$ & F-value & P \\
\hline $\begin{array}{c}\text { Life stages of } \\
\text { host (5) }\end{array}$ & 9.611 & 0.248 & 9.332 & 0.007 & 7.85 & 0.002 & 7.885 & 0.325 \\
\hline Replications (2) & 4.122 & 0.025 & 4.004 & 0.026 & 5.325 & 0.017 & 5.437 & 0.019 \\
\hline $\begin{array}{c}\text { Host } \\
\text { Replication }\end{array}$ & 6.769 & 0.006 & 6.57 & 0.009 & 6.267 & 0.004 & 10.006 & 0.005 \\
\hline
\end{tabular}

From the results it is revealed that developmental period, longevity, prey consumption, survivability, body size and number of adults $X$. flavipes differed depending on the life stages of the prey insect, $R$. dominica. Growth and development of an organism fully depend on their food, light, temperature and humidity. The predator $X$. flavipes preys on a number of insect species of the stored food commodities, and the biological parameters of the predator were found to differ according to the prey species. The total developmental time of the predator was reported as $16.53 \pm 0.13 \mathrm{~d}$ when preyed on

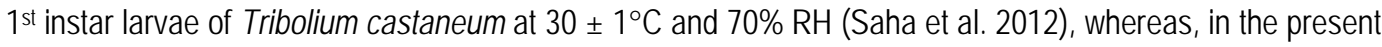
experiment the total developmental time of the predator was recorded minimum as $12 \pm 1.15 \mathrm{~d}$ when preyed on $4^{\text {th }}$ instar larvae of $R$. dominica at similar temperature and relative humidity. So, development of the predator is faster when it feds on larval instars of $R$. dominica than when fed on larvae of $T$. castaneum.

According to Brower and Press (1992) and Abdel-Rahman et al. (1978-79), C. pusillus and Rhizopertha dominica were the most suitable prey of $X$. flavipes. The predator developed faster, lived longer as an adult, survived better in the immature stage and laid more eggs when fed on coleopteran larvae rather than lepidopteran larvae (Abdel-Rahman et al. 1978-79). As intrinsic factors both temperature and relative humidity considerably affect the duration of nymphal and adult stages of $X$. flavipes (Abdel-Rahman et al. 1977 and Arbogast 1978), however, throughout the present experiment both the factors were kept constant.

At $30^{\circ} \mathrm{C}$ temperature $X$. flavipes passes five nymphal instars, and the instar number may vary from 2-6 (Arbogast et al. 1971, Awadullah and Tawfik 1973) depending on the prey, temperature and humidity. On Plodia interpunctella at $30^{\circ} \mathrm{C}$ temperature, total life span of the predator was found as $14-21 \mathrm{~d}$ (Arbogast 1975). In the present study mean developmental periods of nymphal instar was obtained as $12 \pm 1.15-20 \pm$ $0.58 \mathrm{~d}$ feeding on different life stages of $R$. dominica.

Awadallah and Tawfik (1973) reported that adult males and females of $X$. flavipes when provided with $T$. castaneum, lived for 5-43 and 4-37 d respectively on an average. However, the present study revealed that the adult males lived for $5 \pm 0.58$ to $18 \pm 0.58 \mathrm{~d}$ and the adult females lived for $15 \pm 1.15$ to $34 \pm 2.31 \mathrm{~d}$ feeding on different life stages of $R$. dominica, respectively at $30^{\circ} \mathrm{C}$. Whereas, when temperature was $35^{\circ} \mathrm{C}$ and fed on $T$. castaneum, development of the eggs and the nymphal stages were decreased and shortened the longevity of the adults of $X$. flavipes (Abdel-Rahman et al. 1977).

Daily consumption rate of adults varies with the size and life stage of the prey, and gut capacity of the predator. X. flavipes killed significantly more 'stimulating' larval prey than 'easy' egg prey (Lecato and Arbogast 1979, Russo and Vasta 2004). Lecato and Collins (1976) mentioned that $X$. flavipes destroys large 
quantities of prey when the prey was abundant. In the present study it was observed that when an excess of eggs, $1^{\text {st }}, 2^{\text {nd }}, 3^{\text {rd }}$, $4^{\text {th }}$ instar larvae and pupae of $R$. dominica were provided, each predator killed an average of 300 eggs, 49 larvae and 25 pupae of the prey, but when different life stages of the host were provided separately, each predator destroyed an average of 400 eggs, 60 larvae and 28 pupae. The predator when preyed on the larvae of different pest insects separately, it fed on 105 larvae of Corcyra cephalonica, 112 larvae of $T$. confusum, 30 larvae of Stegobium panicerum, 148 larvae of Lasioderma serriocorni during 43 days of life span (Awadallah et al. 1986). The present study reveals that mass culture of the predatory bug, $X$. flavipes can be developed on $R$. dominica in the laboratory to get easy and abundant supply of the bug as a biological control agent.

\section{References}

Abdel-Rahman HA, Shaumar NF, Soliman ZA and El-Agoze MM (1977). Biological studies on the anthocorid bug, Xylocoris flavipes (Reuter). Bulletin de la societe Entomologique d' Egypte, 61: 45-51.

Abdel-Rahman HA, Shaumrar NF, Soliman ZA and El-Agoze MM (1978-79). Efficiency of the Anthocoridae predator Xylocoris flavipes (Reuter). In: Biological Control of stored Grain Insects. Bulletin de la Societe Entomolgique Egypte (Economic), 11: 27-34.

Ahmed KN, M Khatun and MM Rahman (1991). Biological notes on Xylocoris flavipes Reuter (Hemiptera: Anthocoridae). Journal of Asiatic Society of Bangladesh Science, 17: 65-67.

Anonymous (1990). Agro-pesticides: properties and function in Integrated Crop Protection. United Nations Economic and Social commission for Asia and the Pacific. pp. 109-135.

Arbogast RT (1975). Population growth of Xylocoris flavipes Reuter: influence of temperature and humidity, Environmental Entomology, 4(5): 825-831.

Arbogast RT (1976). Suppression of Oryzaephilus surinamensis L. (Coleoptera: Cucujidae) on shelled corn by the predator Xylocoris flavipes Reuter (Hemiptera: Anthocoridae). Journal Georgia Entomological Society, 11: 67-71.

Arbogast RT (1978). The biology and impact of the predatory bug Xylocoris flavipes Reuter. Proceddings $2^{\text {nd }}$ International Conference Stored Product Entomology Ibadan, Nigeria, September 10-16, pp. 91-105.

Arbogast RT, Carthon M and Roberts JR (1971). Developmental stages of Xylocoris flavipes (Hemiptera: Anthocoridae), a predator of stored product insects, Annals of Entomological Society of America, 64: 1131-1134.

Awadallah KT and Tawfik MFS (1973). The biology of Xylocoris flavipes Reuter. (Hemiptera: Anthocoridae). Bulletin de la Societe Entomologique d' Egypte, 56: 177-189.

Awadallah KT, Tawfik MFS and El-Husseini MM (1986). Bio-cycle of the anthocorid predator Xylocoris flavipes Reuter in association with rearing on major pests of stored drug materials, Bulletin de la Societe Entomologique d' Egypte, 66: 27-33.

Birch LC (1945a). The mortality of the immature stages of Calandra oryzae L. (small strain) and Rhizopertha dominica F. in wheat of different moisture contents. Australian Journal Experimental Biology and Medical Science, 23: 141-145.

Birch LC (1945b). The influence of temperature on the development of the different stages of Calandra oryzae L. and Rhizopertha dominica F. (Coleoptera). Australian Journal Experimental Biology and Medical Science, 23: 29-35.

Birch LC (1945c). The influence of temperature, humidity and density on the oviposition of the small strain of Caladra oryzae L. and Rhizopertha dominica F. (Coleoptera). Australian Journal of Experimental Biology and Medical Science, 23: 197-203.

Brower JH and Press JW (1992). Suppression of residual populations of stored product pests in empty corn bins by releasing the predator Xylocoris flavipes Reuter. Biological Control, 2(1): 66-72. 
Brower JH, Smith L, Vail PV and Flinn PW (1996). Biological Control. In Management of insects in stored products, Hagstrum DW and Subramanyam Bh (Eds.), Marcel Dekker, New York, pp. 223-286.

Burkholder WE and Faustini DL (1991). Biological methods of survey and control. In: Ecology and Management of Food Industry Pests (JR Gorham ed), AOAC Press, pp. 361-372.

Daglish GJ and Wallbank BE (2002). Searching for candidate insecticides for disinfestation and protection of grain, In: Wright EJ, Banks HJ, Highley E (Eds.), Stored Grain in Australia 2000, CSIRO Stored Grain Research Laboratory, Canberra, pp. 169-173.

Daglish GJ and Nayak MK (2006). Long-term persistence and efficacy of spinosad against Rhyzopertha dominica (Coleoptera: Bostrychidae) in wheat. Pest Management Science, 62: 148-152.

Edde P (2012). A review of the biology and control of Rhizopertha dominica (F.) the lesser grain borer. Journal of Stored Products Research, 48: 1-18

Ferdous J (2006). Effect of the predator Xylocoris flavipes Reuter and the insect growth regulators triflumuron and diflumuron on Tribolium castaneum Herbst, PhD Thesis, Rajshahi University, Rajshahi, Bangladesh, pp. 168.

Ferdous J, W Islam and S Parween (2009). Biology and mass culture of the Warehouse Pirate Bug Xylochoris flavipes (Reuter) (Hemiptera: Anthocoridae). Bangladesh Journal of Zoology, 37(2): 273-280.

Hansen LS (2010). Health risks and safety hazards related to insects and mites in stored products, International European Symposium on Stored Product "Stress on Chemical Products". Julius-Khun-Archive, 429: 8-9.

Hagstrum DW, Reed C and Kenkel P (1999). Management of stored wheat pests in the USA. International Pest Management Review, 4: 127-142.

Herrera AM, Dalhsten DD, Tomic-Carruthers N and Carruthers RI (2005). Estimating temperature-dependent rates of Diorhabda elongate (Coleoptera: Chrysomalidae) a biological agent of Saltceder (Tamarix spp.). Environmental Entomology, 34(4): 775-784.

Hill EG (1978). Controlling Insect Pests in Flour Mills. MAFF London, H M Stationary Office. pp. 137.

Imamura T, Murata M and Miyanoshita A (2008). Review: Biological Aspects and Predatory Abilities of Hemipterans Attacking Stored-Product Insects. JARQ, 42(1): 1-6.

Jay E, Davis R and Brown S (1968). Studies on the predatious habit of Xylocoris flavipes Reuter (Hemiptera: Anthocoridae). Journal Georgia Entomological Society, 3: 126-130.

Keever DW, Mullen JW, Press JW and Arbogast RT (1986). Augmentation of natural enemies for suppression of two major insect pests in stored farmers stock peanuts. Environmental Entomology, 15: 767-770.

Krishnamurthy K (1975). Post-harvest losses in food grains. Bulletin Grain Technology, 13: 33-49.

Khan AR and Mannan A (1991). Stored-Products Entomology in the Tropics. Agriculture Zoology Review, 4: 67-95.

Lecato GL and Arbogast RT (1979). Functional response of Xylocoris flavipes to Angoumois grain moth and influence of predation on regulation of laboratory populations. Journal Economic Entomology, 72(6): 847-849.

Lecato GL and Davis R (1973). Preference of the predator Xylocoris flavipes Reuter (Hemiptera: Anthocoridae) for species and instars of stored product insects. The Florida Entomologist, 56(1): 57-59.

Lecato GL and Collins JM (1976). Xylocoris flavipes: maximum kill of Tribolium castaneum and minimum kill required for survival of the predator. Environmental Entomology, 5: 1059-1061.

Nayak MK, Daglish GJ and Byrne VS (2005). Effectiveness of spinosad as a grain protectant against resistant beetle and psocid pests of stored grain in Australia. Journal of Stored Product Research, 41: 455- 467.

Park T (1962). Beetles competition and population. Science, 138: 1369-1475. 
Park T and Frank MB (1948). The fecundity and development of the flour beetles, Tribolium castaneum and Tribolium confusum at the three constant temperatures. Ecology 29: 368-375.

Phililips TW, Berberet RC and Cuperus GW (2000). In Francis FJ (ed.), Encyclopedia of Food Science and Technology, $2^{\text {nd }}$ ed. Wiley New York, Post-harvest integrated pest management, pp. 2690-2701.

Pinniger DB, Stubbs MR and Chambers J (1984). The evaluation of some food attractants for the detection of Oryzaephilus surinamensis L. and other storage pests. Proceedings $3^{\text {rd }}$ International Working Conference on Stored Product Entomology, October 23-28, Kansas, USA, pp. 640-650.

Press JW, Flaherty BR and Arbogast RT (1975). Control of the red flour beetle, Tribolium castaneum, in a ware house by a predacious bug, Xylocoris flavipes. Journal Georgia Entomological Society, 10: 76-78.

Press JW, Flaherty BR and Arbogast RT (1976). The effect of low temperature on the egg hatch and subsequent nymphal survival of the predacious bug, Xylocoris flavipes (Hemiptera: Anthocoridae). Journal Georgia Entomological Society, 10: 150-153.

Rahman MM, Islam W and Ahmad KN (2009). Functional response of the predator Xylocoris flavipes to three stored product insect pests. International Journal Agriculture Biology, 11: 316-320.

Russo AC and Vasta GEMC (2004). Life tables of Xylocoris flavipes (Hemiptera: Anthocoridae) feeding on Tribolium castaneum (Coleoptera: Tenebrionidae). Journal Stored Product Research, 40: 103-112.

Saha SR, Islam W and Parween S (2012). Influence of humidity and Tribolium beetle food source on the life history characteristics of predator, Xylocoris flavipes (Hemiptera: Anthocoridae). Tropical Agriculture Research and Extension, 15(1): 8-13.

Scholler M, Prozell S, Al-Kirshi AG and Reichmuth CH (1997). Towards biological control as a major component of integrated pest management in stored product protection. Journal of Stored Product Research, 33: 81-97.

Tukey JW (1953). The problem of multiple comparisons, Department of Statistics, Princeton University.

Vinson SB and Iwantsch GF (1980). Host survivability for insect parasitoids, Annual Review Entomology, 20: 397-419.

Visarathanonth P, Nakakita H and Sittisuang P (1994). Role of natural enemies in the regulation of stored-product insect populations in rice storages in Thailand. JIRCAS Journal, 1:1-7.

Visarathanonth P, Khumlekasing M and Sukprakarn C (1990). Insecticidal control of cowpea weevil, Callosobruchus maculatus F. a pest of mungbean, Bruchids and Legumes: Economics, Ecology and Coevolution (Fujii K, Gatehouse AMR, Johnson CD, Mitchell R and Yoshida T eds.), Kluwer Academic Publishers, Dordrecht, the Netherlands. pp. 101-104.

Watters FL and Shuyler HR (1977). Control of post-harvest losses. FAO Plant Protection Bulletin, 25: 184-188.

Wilbur DA and Mills RB (1978). Stored grain insect. In: Fundamentals of Applied Entomology, 3rd Ed. MacMillan Publishing Co. Inc., pp. 73-81.

Zyromska-Rudzka H (1996). Abundance and emigration of Tribolium in a laboratory model, Ekologia Polska Series A. 14: 491-578. 